\title{
GMNC Gene
}

National Cancer Institute

\section{Source}

National Cancer Institute. GMNC Gene. NCI Thesaurus. Code C126580.

This gene is involved in the modulation of DNA replication. 